\title{
КОМПЕТЕНТНОСТІ МАЙБУТНЬОГО ІНЖЕНЕРА У ПРОЦЕСІ ГРАФІЧНОЇ ПІДГОТОВКИ
}

\begin{abstract}
Цвіркун Л. О. Компетентності майбутнього інженера у процесі графічної підготовки.

У статті розглянуто наукові поняття «компетентнісний підхід», «компетенція», «компетентність», 3'ясовано сутність використовуваних понять в аспекті компетентнісного підходу, виокремлено компетентності майбутнього інженера в процесі графічної підготовки, які $€$ невід’ємним складником проектно-
\end{abstract} конструкторської діяльності.

Ключові слова: компетентнісний підхід, компетенція, компетентність, проектно-конструкторська компетентність, графічна підготовка інженера.

Цвиркун Л. А. Компетентности будущего инженера в процессе графической подготовки.

В статье рассмотрены научные понятия «компетентностный подход», «компетенция», «компетентность», раскрыта сущность используемых понятий в аспекте компетентностного подхода, выделены компетентности будущего инженера в процессе графической подготовки, которые являются неотъемлемой составляющей проектно-конструкторской деятельности.

Ключевые слова: компетентностный подход, компетенция, компетентность, проектно-конструкторская компетентность, графическая подготовка инженера.

Tsvirkun L. O. Competence of the future engineer in the graphic preparation.

The article describes the scientific concept of «competence approach», «competence», "competency» and refine the concepts used in the aspect of the competence approach, emphasis competence future engineer in the preparation of graphics, which are an integral part of design activity.

Key words: competence approach, competence, competency, design and engineering expertise, graphic preparation of the engineer.

У зв'язку з інтеграцією України до європейського освітнього та наукового простору постає необхідною підготовка висококваліфікованого й компетентного фахівця, здатного розв'язувати професійні завдання за встановленими вимогами i стандартами. Провідну роль у цьому процесі покладено на вищі навчальні заклади, які створюють умови для формування й розвитку професійної, дослідної, комунікативної, проектно-конструкторської компетентностей, необхідних для майбутньої успішної діяльності. Про це свідчать Закони України «Про освіту», «Про вищу освіту», у яких освіта $є$ пріоритетною галуззю соціально-економічного, духовного і культурного розвитку суспільства. У названих законах зазначено, що вища освіта забезпечує професійну і практичну підготовку, здобуття громадянами освітньо-кваліфікаційних рівнів відповідно до їхніх покликань та інтересів [3].

Необхідність розвитку професійної компетентності майбутнього фахівця зафіксовано і в Національній доктрині розвитку освіти, у якій приділено увагу заходам щодо підвищення якості освіти в Україні і створення необхідних умов для розвитку, самовдосконалення й самореалізації у професійній діяльності [7].

Останнім часом висуваються нові вимоги і до випускників вищих навчальних закладів, 3-поміж яких усе більшого пріоритету набувають уміння системно 
розв'язувати технічні, інтелектуальні, комунікативні, організаційні та моральні завдання. Фахівцям потрібна не кваліфікація, яка асоціюється 3 умінням здійснювати ті чи ті функції професійного характеру, а насамперед компетентність у відповідній сфері діяльності [1].

Meта статmi - визначити компетентності майбутнього інженера у процесі графічної підготовки, які є невід’ємним складником проектно-конструкторської діяльності.

Одним із напрямів професійної підготовки сучасного інженера $\epsilon$ фундаментальна підготовка, основне завдання якої полягає у формуванні проектноконструкторської компетентності і всебічному розвитку студента як особистості, яка прагне подальшого зростання свого освітнього потенціалу.

Графічна підготовка посідає одне 3 чільних місць у формуванні проектноконструкторської компетентності: під час вивчення графічних дисциплін у студентів відбувається розвиток здатності до аналізу й синтезу графічних моделей і форм, уміння правильно читати креслення і схеми, здійснювати графічну постановку завдань, проектувати, будувати графічні моделі, а також грамотно реалізовувати лаконічну графічну мову, застосовуючи інформаційні технології і графічні системи. Вона активізує процеси просторової пам'яті, уяви, логічного й технічного мислення, сприяє досягненню більш високого рівня розумового розвитку.

Із невпинним розвитком науково-технічного прогресу графічна діяльність може успішно здійснювати лише 3 урахуванням багатьох вимог, пов'язаних із розв'язанням виробничих завдань i суспільним попитом. Майбутній інженер повинен володіти комплексом знань, які грунтуються на науково-теоретичній та інженерно-графічній базі, що у свою чергу, вимагає нового підходу до формування компетентностей у процесі графічної підготовки.

Розв'язування означеної проблеми невід'ємно пов'язане 3 вивченням графічних дисциплін (нарисна геометрія, інженерна й комп'ютерна графіка) на основі компетентнісного підходу. Відповідно постає необхідність запровадження компетентнісного підходу в навчанні студентів графічних дисциплін і створення ефективних механізмів його реалізації.

Так, І. Зимня розглядає компетентнісний підхід у вищій освіті як стратегічний напрямок розвитку всіх компонентів системи освіти, де графічна підготовка $€$ невід'ємним компонентом компетентнісної парадигми вищої освіти [4]. Ця стратегія визначає важливість графічної підготовки студентів технічних ВНЗ.

Науковці, що досліджують проблему компетентнісного підходу в навчанні (I. Агапова, 3. Бакум, В. Болотов, І. Зимня, А. Хуторський та ін.) зазначають, що він передбачає таку організацію навчального процесу, яка спрямована на кінцевий результат майбутню успішну діяльність, зокрема у проектно-конструкторській діяльності.

Зокрема, В. Болотов і В. Серіков уважають, що за компетентнісного підходу на перше місце висувається не інформованість студента, а вміння розв'язувати проблеми, що виникають у процесі засвоєння сучасної техніки і технології, виборі професії та оцінці своєї готовності до навчання у професійному навчальному закладі тощо [2, с. 10-11].

Доцільно згадати Т. Іванову, на думку якої упровадження компетентнісного підходу дозволить значною мірою реалізувати особистісно зорієнтований i діяльнісний підходи в освітньому процесі, оскільки окреслення компетенцій у змісті навчальних предметів визначає орієнтири у відборі тих знань і умінь, які найбільш значущі для формування ціннісних орієнтацій і будуть необхідними в житті самого студента [5]. Отже, упровадження компетентнісного підходу можна розглядати як інструмент розвантаження змісту, відбору відповідних знань і вмінь у процесі навчання студентів графічних дисциплін. 
На основі аналізу науково-педагогічної літератури можна констатувати, що стратегічним завданням компетентнісного підходу є створення умов для набуття студентами досвіду професійної діяльності. Студент повинен оволодіти такою системою графічних знань, яка дозволить йому успішно виконувати проектно-конструкторську роботу й опанувати необхідну для цієї діяльності систему компетенцій та компетентностей.

Науковці (I. Зимня, Е. Зеєр, А. Хуторський, С. Шишов та ін.) зазначають, що найбільш вагомою ознакою компетенції в навчальному процесі є результат навчання. Стосовно предметного аспекту навчання студент повинен оволодіти конкретною компетенцією - отримати сукупність знань і умінь, набути досвіду професійної діяльності, продемонструвати готовність самостійно розв'язувати виробничі завдання.

3 іншого боку, науковці (І. Агапов, С. Шишов) розглядають компетентність як здатність і готовність студента до діяльності, що грунтується на знаннях і досвіді, які набуті завдяки навчанню, зорієнтовані на самостійну участь у навчально-пізнавальному процесі, а також спрямовані на успішне залучення до трудової діяльності [8, с. 12]. Отже, компетентність - володіння певною компетенцією, яка виявляється в загальній здатності до діяльності, заснована на готовності демонструвати уміння й навички, досвіді, та зорієнтована на самостійну успішну професійну діяльність.

Розглядаючи компетентнісний підхід у навчання студентів графічних дисциплін, можна зазначити, що вагомим є визначення компетентностей, завдяки яким студент зможе професійно реалізуватися у проектно-конструкторській діяльності:

1. Пізнавальна компетентність - здатність застосовувати увміння та навички у процесі розв'язування інженерно-графічних завдань засобами нарисної геометрії й інженерної графіки, а також у самостійній пізнавальній діяльності:

- використовувати стандарти ЕСКД (Єдиної системи конструкторської документації), методичні матеріали;

- виконувати проектно-конструкторські роботи із застосуванням методів нарисної геометрії й інженерної графіки;

- створювати ескізи, креслення та схеми;

- читати й аналізувати креслення, виправляти власні помилки;

- самостійно здобувати знання, необхідні для креативної і творчої діяльності.

Нині у процесі вивчення графічних дисциплін використовуються сучасні програмні системи: Компас, AutoCad, CorelDraw тощо. Застосування комп'ютерних технологій автоматизованого управління сприяє посиленню мотиваційно-пізнавальної та самостійної діяльності студентів у процесі графічної підготовки. Це надає змогу визначити компетентність, необхідну у проектно-конструкторській діяльності.

2. Інформаційна компетентність - готовність застосовувати уміння й навички використання інформаційно-комунікаційних технологій (IКT) у процесі розв'язування графічних завдань:

- створювати інженерно-графічні роботи за допомогою сучасних графічних систем (Компас, AutoCad, CorelDraw);

- розробляти робочу проектну й технічну документацію;

- оформлювати завершені проектно-конструкторські роботи;

- самостійно набувати нових знань із використанням сучасних інформаційних технологій;

- реалізовувати творчі здібності за допомогою сучасних графічних систем.

Нині майбутній інженер повинен не тільки мати знання щодо розв'язування професійних завдань, але й застосовувати свої уміння в потрібний момент, усвідомлювати соціальну значущість та особистісну відповідальність за результати власної діяльності. 
Випускники вищих навчальних закладів мають сформовані професійні знання. Сучасна вища школа формує основи професійної компетентності інженера, що дозволяє іiі випускникам створювати об'єкти, що відповідають технічним вимогам і стандартам якості. Однак у практичній діяльності вчорашні студенти не завжди виявляють гнучкість, маневреність, варіативність рішень. Найчастіше в них недостатньо розвинене творче бачення подальшої перспективи [6].

3. Сочіальна компетентність - здатність застосовувати вміння й навички в різних ситуаціях виробничої діяльності.

Структурну схему компетентностей майбутнього інженера у процесі графічної підготовки подано в табл. 1.

Таблиця 1.1

Компетентності майбутнього інженера у процесі графічної підготовки

Проектно-конструкторська компетентність майбутнього інженера

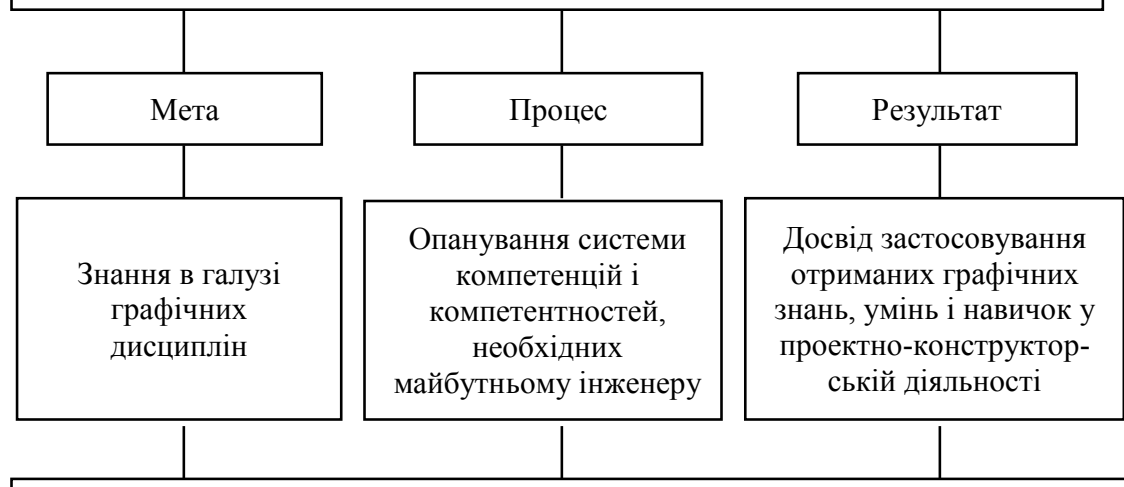

Компетентності у процесі вивчення графічних дисциплін

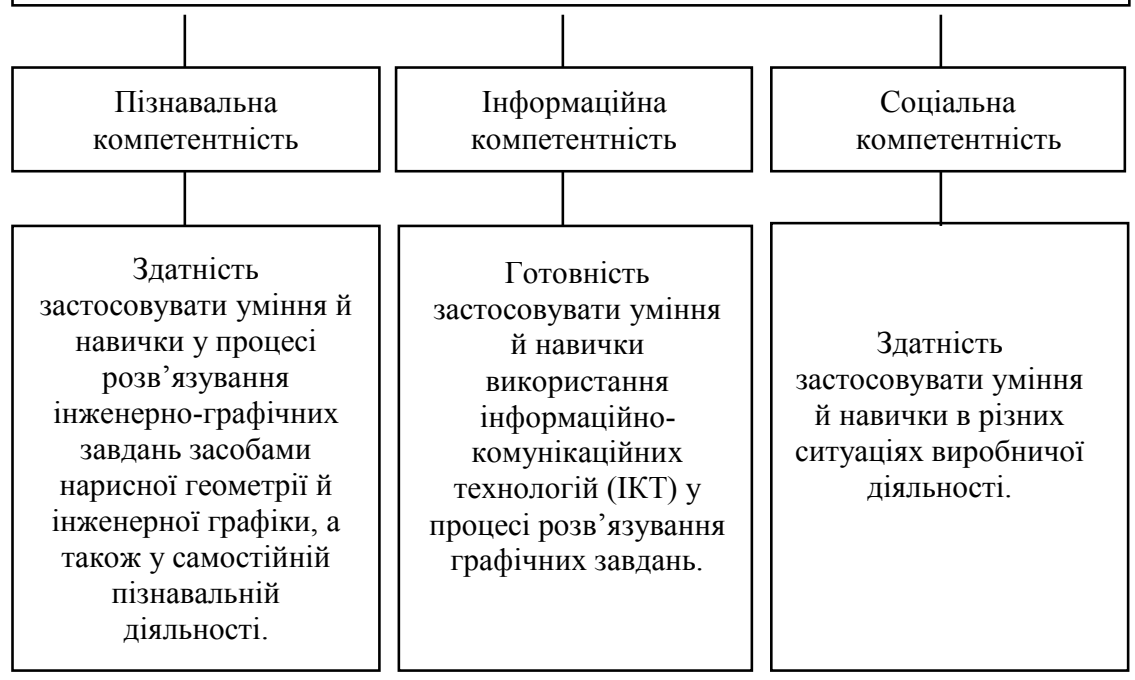


Отже, потреба у висококваліфікованих фахівцях інженерної галузі, що володіють на належному рівні проектно-конструкторською компетентністю, залишається питанням, яке потребує подальших досліджень. Водночас студент має засвоїти знання й оволодіти графічними вміннями й навичками, які дозволять йому успішно здійснювати проектно-конструкторську діяльність; опанувати необхідну сукупність компетентностей для цієї діяльності у процесі графічної підготовки.

\section{Література}

1. Доклад международной комиссии по образованию, представленный ЮНЕСКО «Образование: сокрытое сокровище». - М. : ЮНЕСКО, 1996. - 31 с. 2. Болотов В. А. Компетентностная модель: от идеи к образовательной программе / В. А. Болотов, В. В. Сериков // Педагогика. - 2003. -№ 10. - С. 8-14. 3. Закон України «Про вищу освіту» № 2984-III від 17 січня 2002 р. // Вісник Верховної Ради України. - 2002. - № 20. - С. 134. 4. Зимняя И. Ключевые компетенции - новая парадигма результата образования / И. Зимняя// Высшее образование сегодня. 2003. - № 5. - С. 34-42. 5. Иванова Т. В. Компетентностный подход к разработке стандартов для 11-летней школы: анализ, проблемы, выводы / Т. В. Иванова // Стандарты и мониторинг в образовании. - 2004. - №1. - С. 16-20. 6. Муравлев И. О. Формирование специалистов в области техники и технологии для инновационной инженерной деятельности [Электронный ресурс]/ И. О. Муравлев, О. В. Блейхер. - Режим доступу: http://aeer.cctpu.edu.ru /winn/magazine/m2/st25.pdf. 7. Указ Президента України «Про Національну стратегію розвитку освіти в Україні на період до 2021 року» від 25 червня 2013 року №344/2013/ [Електронний ресурс]. - Режим доступу: http://zakon2.rada.gov.ua/laws/show/344/2013. 8. Шишов С. Е. Компетентностный подход к образованию как необходимость / С. Е. Шишов, И. Г. Агапов // Мир образования - образование в мире. - 2001. - № 4. - С. 8-19.

УДК $378.011 .3: 338.48-051$

Галина Щука

\section{ОРГАНІЗАЦІЯ НАВЧАЛЬНИХ ТА ВИРОБНИЧИХ ПРАКТИК У ПРОЦЕСІ ПІДГОТОВКИ ФАХІВЦІВ СФЕРИ ТУРИЗМУ}

Щука Г. П. Організація навчальних та виробничих практик у процесі підготовки фахівців сфери туризму.

У статті аналізується рівень організації навчальних і виробничих практик у процесі підготовки вітчизняних бакалаврів 3 туризму. Автором оцінюється нормативна тривалість практик та встановлюються можливості іiї подовження; розглядається дієва технологія проектування процесу практичної підготовки та визначаються іiі недоліки; уточнюється принцип формування змісту практик та простежується зв'язок теоретичної та практичної підготовки.

Ключові слова: туризм, практика, галузевий стандарт вищої освіти, напрям підготовки «Туризм», бакалавр з туризму.

Щука Г. П. Организация учебных и производственных практик в процессе подготовки специалистов сферы туризма.

В статье анализируется уровень организации учебных и производственных практик в процессе подготовки отечественных бакалавров туризма. Автором оценивается нормативная продолжительность практик и устанавливаются возможности еe продления; рассматривается действующая технология 